The World Computer 
THOUGHT IN THE ACT

A series edited by Erin Manning and Brian Massumi 


\title{
The World Computer
}

\author{
Derivative Conditions \\ of Racial Capitalism
}

JONATHAN BELLER 
(C) 202I Duke University Press

All rights reserved

Printed in the United States of America on acid-free paper $\infty$

Designed by Drew Sisk

Typeset in Portrait Text and IBM Plex Mono by

Westchester Publishing Services

Library of Congress Cataloging-in-Publication Data

Names: Beller, Jonathan, author.

Title: The world computer : derivative conditions of racial capitalism /

Jonathan Beller.

Other titles: Thought in the act.

Description: Durham : Duke University Press, 202I. | Series: Thought in the act | Includes bibliographical references and index.

Identifiers: LCCN 2020029359 (print) | LCCN 2020029360 (ebook)

ISBN 978I4780I0I35 (hardcover)

ISBN 978I4780III63 (paperback)

ISBN 978I4780I2702 (ebook)

Subjects: LCSH: Mass media-Social aspects. | Digital media-Social aspects. | Race in mass media.

Classification: LCC HMI2O6 .B455 202I (print) | LCC HMI2O6 (ebook) | DDC 302.23-dc23

LC record available at https://lccn.loc.gov/2020029359

LC ebook record available at https://lccn.loc.gov/2020029360

Cover art: Thomas Ruff, r.phg.IO, 20I4. Chromogenic print, $94^{1 / 2} \times 72^{7 / 8}$ inches, $240 \times 185 \mathrm{~cm}$. (C) 2020 Thomas Ruff / Artists Rights Society (ARS), New York / VG Bild-Kunst, Germany. Courtesy the artist and David Zwirner. 
For those who are written, unwritten, rewritten, and read 
This page intentionally left blank 
The technical subordination of the worker to the uniform motion of the instruments of labor, and the peculiar composition of the working group, consisting as it does of individuals of both sexes and all ages, gives rise to a barrack-like discipline, which is elaborated into a complete system in the factory, and brings the previously mentioned labor of superintendence to its fullest development, thereby dividing the workers into manual laborers and overseers, into the private soldiers and the NCOs of an industrial army. "The main difficulty" (in the automatic factory) "lay ... above all in training human beings to renounce their desultory habits of work, and to identify themselves with the unvarying regularity of complex automations. To devise and administer a successful code of factory discipline, suited to the necessities of factory diligence, was the Herculean enterprise, the noble achievement of Arkwright! Even at the present day, when the system is perfectly organized and its labor lightened to the utmost, it is found nearly impossible to convert persons past the age of puberty into useful factory hands." In the factory code, the capitalist formulates his autocratic power over his workers like a private legislator, and purely as an emanation of his own will, unaccompanied by either that division of responsibility otherwise so much approved by the bourgeoisie, or the still more approved representative system. The code is merely the capitalist caricature of the social regulation of the labor process which becomes necessary in co-operation on a large scale and in the employment in common of instruments of labor, and especially of machinery. The overseer's book of penalties replaces the slave-driver's lash. All punishments naturally resolve themselves into fines and deductions from wages, and the law-giving talent of the factory Lycurgus so arranges matters that a violation of his laws is, if possible, more profitable to him than the keeping of them.

-KARL MARX, CAPITAL

Europe is literally the creation of the third world.

-FRANTZ FANON, THE WRETCHED OF THE EARTH

You fucked the world up now, we'll fuck it all back down.

-JANELLE MONÁE, "SCREWED," DIRTY COMPUTER 
This page intentionally left blank 